10. Folsom v. Marsh, 9 F. Cas. 342 (C.C.D. Mass. 1841) (No. 4901). Retrieved from: http://c.ymcdn.com/sites/www.musiclibraryassoc.org/resource/ resmgr/copyright/FolsomvMarsh.pdf. (in English).

11. Sobol M. N. (2015). Istoki doktrinyi dobrosovestnogo ispolzovaniya proizvedeniy $v$ knigopechatanii i zhurnalistike Anglii i SShA.[The origins of the doctrine of conscientious use of works in printing and journalism in England and the United States]. Medyaskop. №2. Retrieved from: URL: http://www.mediascope.ru/1765. (In Russian).

12. Avtorske pravo dlia bibliotekariv. (2015). [Copyright for librarians]. (O. Vasyliev, Trans). K.: TOV "IMM "FRAKSIM", 196 . Retrieved from: www.informatio-consortium.net/infodoc/Copyright\%20fo. (In Ukrainian).

13. Postanova Kabinetu ministriv Ukrainy Pro zatverdzhennia minimalnykh stavok vynahorody (roialti) za vykorystannia obiektiv avtorskoho prava i sumizhnykh prav. [About the statement of the minimum rates of a reward (royalties) for use of objects of copyright and the related rights]. (2003, January 18). Retrieved from:https://zakon.rada.gov.ua/ laws/show/72-2003-\%D0\%BF\#Text. (In Ukrainian).

14. Philpot v. Media Research Center Inc. No. 1:17-cv-822 (E.D. Va Jan. 8, 2018). Retrieved from: https://casetext.com/case/philpot-v-mediaresearch-ctr-inc. (in English)

Yu. Akulov, PhD Student (Law)

Taras Shevchenko National University of Kyiv, Kyiv, Ukraine

\title{
RESTRICTIONS ON COPYRIGHT IN UKRAINE AND THE UNITED STATES: \\ A COMPARATIVE LEGAL ASPECT
}

The article compares the American copyright system (from its inception, borrowing the basics of the English system to the establishment of the principle of "fair use") and the Ukrainian system, which provides a specific list of cases allowed as a restriction of copyright (enumerated system) by establishing in national legal acts of the three-stage test provided by the Berne Convention.

The article examines not only the legislation of Ukraine and the United States in this area, such as: the Federal Copyright Act of 1790, the second Federal Copyright Act of 1909, the Copyright Act of 1976, the Civil Code of Ukraine, the Law of Ukraine "On Copyright law and related rights" but also the case law of the United States, which is a key element in regulating disputes in the area under discussion. The author analyzes a number of cases through the prism of changing approaches in the US system of property rights restrictions, namely Philpot v. Media Research Center Inc. No. 1: 17-cv-822 dated January 8, 2018; Peteski Productions, Inc. v. Leah Rothman No. 5: 17-CV-00122 dated August 30, 2017; Rosen v. eBay, Inc., No. 2: 13-cv-06801-MWF-E of 16 January 2015 and Corbello v. DeVito No. 2: 08-cv-00867-RCJ-PAL June 14, 2017.

As a result of the research, the author determines that the national legislation establishes an exhaustive list of works that are its objects, at the same time, the ways of using the work depend on the type of particular work. Therefore, an exhaustive list of all possible ways to use the works is not provided. U.S. law provides for an exhaustive list of copyrighted works and an exhaustive list of ways to use such works. And the doctrine of "fair use" in the United States provides that in determining whether the use of work in any particular case is fair, there are at least 4 factors to consider.

Keywords: the principle of "enumerated system", the system of "numerus clausus", the concept of "exceptions and limitations", US copyright law, the doctrine of fair use, the Agreement on guidelines for copying in non-profit educational institutions, free use of works, three-stage test.

Bulletin of Taras Shevchenko National University of Kyiv.

Legal Studies, 2021; 2 (117): 10-14

УДК: 378:37.033

DOI: https:doi.org/10.17721/1728-2195/2021/2.117-2
ISSN 1728-2195

Taras Shevchenko National University of Kyiv,

Publishing center "Kyiv University", 2021

Ю. Баклаженко, канд. пед. наук, доц. ORCID ID: 0000-0002-9035-7737

НТУУ "Київський політехнічний інститут імені Ігоря Сікорського", Київ, Україна

\section{ОСОБЛИВОСТІ ПЕРЕКЛАДУ ЮРИДИЧНИХ НЕОЛОГІЗМІВ НА ПРИКЛАДІ ТЕРМІНА "МАЛОЗНАЧНА СПРАВА"1}

Тема юридичного перекладу з англійської мови на українську та навпаки стала особливо актуальною після набуття чинності Угоди про асоціацію між Україною та ЄС і спричинена необхідністю забезпечення перекладів великого корпусу документів економічного й юридичного характеру у сфері транскордонної співпраці. Статтю присвячено проблемі перекладу юридичної термінології з української мови на англійську на прикладі дослідження нового в українському законодавстві терміна "малозначна справа". У статті розглянуто поняття еквівалентності як одне з найбільш дискусійних питань у теорії перекладу, а також визначається необхідність проведення концептуального аналізу та гармонізації терміносистем у юридичному дискурсі. Автором проведено зіставний понятійний аналіз термінів зі спрощених процедур ЄС та України - малозначна справа та дрібний позов, у результаті якого робиться висновок, що, незважаючи на поверхневу схожість із терміном ЄC "small claim", український термін "малозначна справа" є насправді набагато шириим поняттям. У статmі також описано способи перекладу юридичних неологізмів (до яких належить, зокрема і термін "малозначна справа"). У результаті аналізу можливих варіантів перекладу та прецеденту перекладу ЄСПЛ рекомендується перекладати термін цивільного судочинства України "малозначна справа" англійською мовою у спосіб буквального перекладу як "insignificant case".

Ключові слова: малозначна справа, дрібний позов, юридичний переклад, гармонізація термінів, еквівалентний переклад.

ВСтУП. Наближення українського законодавства до права ЄС є однією з цілей Угоди про асоціацію між Україною та ЄС [4]. Коли угода набрала чинності в повному обсязі 2017 р., виникла нагальна потреба у перекладі нормативних документів і законодавчих текстів з англійської мови на українську та навпаки. У перспективі, у разі входження України до Європейського Співтовариства, українською мовою доведеться перекласти всю законодавчу базу $€ С$, тобто близько 108000 документів, включаючи договори ЄС, закони, міжнародні угоди та стандарти [1]. Це величезний обсяг роботи з огляду, що окремий документ - наприклад, сама Угода про

Статтю підготовлено на основі перекладу матеріалів, опублікованих раніше (див. Yu. Baklazhenko, 'Ukrainian-English Translation of Legal Terms: A Case Study of Insignificant Cases and Small Claims' 2021. 1(9) Access to Justice in Eastern Europe 232242. DOI: 10.33327/AJEE-18-4.1-n000055). 
асоціацію між Україною та ЄС - може містити понад 1200 сторінок. Більше того, згідно з принципом мультилінгвізму, усі поправки та зміни, що постійно виникають у законодавчій базі $€ C$, також мають бути перекладені 24 офріційними мовами ЄС. Таким чином, процес юридичного перекладу в ЄС має постійний і невпинний характер. Це визначає актуальність досліджень із теорії та практики юридичного перекладу з англійської мови на українську і навпаки. Метою цієї статті $є$ з'ясування характерних особливостей юридичного перекладу, зокрема, понять еквівалентності в юридичному перекладі, гармонізації юридичних терміносистем, а також аналіз перекладу англійською мовою нового терміна "малозначна справа" у спрощеному цивільному судочинстві України. У статті застосовано методи аналізу та синтезу наукової літератури з проблематики дослідження, понятійний аналіз термінів, зіставлення та порівняння термінологій двох мовних систем у юридичній сфрері.

\section{ВИКЛАД ОСНОВНОГО МАТЕРІАЛУ}

Перекладацька еквівалентність i гармонізація терміносистем у юридичному перекладі. Основними елементами теорії перекладу є вихідний текст (той, що підлягає перекладу) та цільовий текст (результат перекладу), а відтак - мова оригіналу та мова перекладу. Метою перекладу $€$ створення еквівалентного тексту мовою перекладу. Як вказує Дж. Кеторорд [7], тексти мовою оригіналу та мовою перекладу еквівалентні, якщо вони взаємозамінні в певній ситуації. Складність юридичного перекладу полягає, перш за все у тому, що за юридичного перекладу перекладач повинен передавати не лише повідомлення, висловлене мовою оригіналу, а й зберігати культурні (відтак, юридичні, оскільки право та культура тісно взаємопов'язані) відмінності між мовами [8]. За таких умов, забезпечення взаємозамінності й еквівалентності оригіналу та перекладу юридичних реалій і термінів у мовах країн, що належать до різних правових систем, мають різні правові традиції, й історичний досвід $є$ надзвичайно вимогливим завданням.

Поняття еквівалентності - одне з найбільш дискусійних наріжних каменів у теорії перекладу, що містить кілька аспектів. В. Коллер [15] визначає п'ять типів еквівалентності: "денотативна еквівалентність", що стосується змісту, переданого текстом, "конотативна еквівалентність", яка пов'язана із соціальними та регіональними конотаціями; "жанрова еквівалентність", що належить до певних типів тексту та жанрів; "прагматична еквівалентність", пов'язана з орієнтацією на аудиторію, та "формальна еквівалентність", що стосується специфічних особливостей естетичної форми чи індивідуального стилю. Переклад має відповідати всім цим критеріям еквівалентності, щоб належним чином відображати концепцію, намір, мету та фрорму тексту у певних лінгвістичних та екстралінгвістичних вимірах. 3 огляду на те, що вимоги до еквівалентного перекладу високі, а в деяких випадках навіть недосяжні, деякі лінгвісти дійшли висновку, що симетрія в перекладі $є$ ілюзією, і що поняття еквівалентності може бути дуже проблематичним [16]. Це стосується, передусім, юридичного перекладу, який часто розглядається як найвимогливіший тип перекладу, оскільки перекладач має одночасно бути перекладачем відповідної правової системи. Через суттєві відмінності різних правових систем, саме юридичний переклад часто ототожнюють із неперекладністю.

У перекладознавчих дослідженнях еквівалентність включає не лише взаємозв'язок між текстами, а й між окремими мовними знаками (словами, словосполучен- нями, термінами). Проблема дублікатних і суперечливих термінів завжди існувала в багатьох сферах науки i техніки через те, що поняття та терміни в окремих мовах розвиваються по-різному, залежно від професійних, технічних, наукових, соціальних, економічних, лінгвістичних, культурних та інших фракторів. Невідповідність між термінологічними поняттями та термінами створює комунікативні бар'єри, оскільки вживання термінів, подібних зовні, але навіть незначною мірою різних за значенням, призводить до помилкового їх тлумачення і може спричинити їхнє подальше хибне використання та розповсюдження. Для розв'язання цього питання розроблено стандарт ISO 860: 2007 "Термінологічна робота - гармонізація понять і термінів" [11], у якому акцентується увага на тому, що для забезпечення послідовного та належного перекладу термінів слід, перш за все, узгодити їхні значення, тобто поняття, які вони позначають. Така гармонізація важлива, оскільки конотативні відмінності не обов'язково стають очевидними на денотативному рівні.

Як зазначено у стандарті, гармонізація системи понять - це не перенесення системи понять на іншу мову, навпаки, вона включає порівняння й узгодження систем понять в одній або декількох мовах або предметних областях. Гармонізація понять означає діяльність, що веде до встановлення відповідності між двома або більше тісно пов'язаними або дублюючими поняттями, що мають професійні, технічні, наукові, соціальні, економічні, мовні, культурні й інші відмінності. Такий процес супроводжується гармонізацією термінів - діяльністю, що веде до ретельного підбору позначень для гармонізованого поняття різними мовами або однією мовою. Варто зазначити, що гармонізація термінів можлива лише тоді, коли поняття, що представляють ці терміни, є майже абсолютно однаковими.

Гармонізація термінології в $€ С €$ складним завданням, оскільки вона повинна враховувати відмінності між використанням термінів у різних країнах-членах. Наднаціональні терміни (терміни у законодавстві $€ C$ ) повинні мати 24 еквіваленти в національних законодавствах (країн-членів ЄС), при цьому суто національні терміни мають відрізнятися від наднаціональних для уникнення їх хибного тлумачення. Б. Дефранк [9], говорячи про особливості юридичного перекладу в $Є С$, зазначив, що термінологія внутрішнього законодавства країнчленів має бути автономною від термінів законодавства $€ С$. Це означає, що в законодавчих межах ЄС діє термінологічна система, яка відокремлена від відповідних термінологічних систем країн-членів. Для уникнення термінологічної омонімії інколи навіть виникає необхідність замінювати загальновизнані терміни. Наприклад, термін "civil service" у договорах ЄС замінюють терміном "public service", слово "undertaking" використовують замість "company", "large goods vehicle" - замість "lorry" та "state aid" - замість "subsidy" [9]. Такі терміни називають "декультуралізованими" [6]. Використання декультуралізованих термінів необхідне для забезпечення однозначності законодавства ЄС. Для перекладу української термінології англійською мовою з огляду на євроінтеграційний вектор розвитку, необхідно враховувати внутрішній досвід перекладів у Співтоваристві та належним чином гармонізувати поняття.

Переклад українського терміна "малозначна справа" англійською мовою у сфері спрощеного цивільного провадження. Забезпечення термінологі- 
чної еквівалентності й однозначності є однією з найскладніших проблем, що виникають у процесі перекладу юридичних термінів, зокрема у ссрері нещодавно запровадженого спрощеного цивільного провадження в українському законодавстві. Як ми вже згадували, спрощене провадження покликано встановити в Україні подібні до ЄС цивільно-процесуальні механізми, однак указана подібність може призвести до бажання оперувати у перекладі тими самими поняттями та термінами, які вживаються у процедурах ЄС та України, що не завжди виправдано. У випадку перекладу положень українського спрощеного цивільного провадження англійською мовою, задачею перекладача є ретельне оцінювання співвідношення між термінами, що використовуються в обох провадженнях (спрощена процедура $€ С$ та України), щоб уникнути потенційних підводних каменів у перекладі подібних на перший погляд концепцій. Розглянемо детальніше переклад юридичного неологізму "малозначна справа", запроваджений українським законодавцем у спрощеному цивільному провадженні, та його співвідношення з термінами Процедури розгляду дрібних позовів ЄС.

Співвідношення термінів "дрібний позов" $і$ "малозначна справа": концептуальний аналіз.

Першим кроком у процесі перекладу юридичного терміна $€$ аналіз того, чи існує співвідносний термін у мові перекладу, та, за його наявності, оцінювання того, наскільки гармонізованими $є$ термінологічні концепції. Як в українському законодавстві, так і в законодавстві $€ C €$ спрощені процедури розгляду цивільних справ, у межах яких діють терміни "малозначна справа" та "small claim" - дрібний позов. 3'ясуємо, наскільки співвіднесений понятійний зміст цих термінів.

Відповідно до ч. 1 ст. 274 Цивільного процесуального кодексу України (ЦПК) [3], за спрощеним позовним провадженням розглядають справи:

1) малозначні;

2) що виникають із трудових відносин;

3) про надання судом дозволу на тимчасовий виїзд дитини за межі України тому з батьків, хто проживає окремо від дитини, у якого відсутня заборгованість зі сплати аліментів та якому відмовлено другим із батьків у наданні нотаріально посвідченої згоди на такий виїзд.

Причому поняття "малозначні справи" потребує роз'яснення і пояснюється в самому КПК. Відповідно до ч. 6 ст.19 ЦПК, малозначними справами є:

1) справи, у яких ціна позову не перевищує ста розмірів прожиткового мінімуму для працездатних осіб (станом на 1 січня 2021 р. - 218900 грн., що на 6 січня 2021 р. становить 6265 євро);

2) справи незначної складності, визнані судом малозначними, крім справ, які підлягають розгляду лише за правилами загального позовного провадження, та справ, ціна позову в яких перевищує п'ятсот розмірів прожиткового мінімуму для працездатних осіб (станом на 1 січня 2021 р. - 1094500 грн., що на 31 січня 2021 р. становить 31325 євро).

Як зазначено в Регламенті (ЄС) 2015/2421 Європейського Парламенту та Ради від 16 грудня 2015 р. про внесення змін до Регламенту (ЄC) № 861/2007, що встановлює Європейську процедуру розгляду дрібних позовів і Регламенту (ЄC) No 1896/2006 про створення Європейської процедури стягнення у справах щодо неоспорюваних грошових вимог [19], процедура розгляду дрібних позовів застосовується у транскордонних цивільних і комерційних справах, незалежно від характеру суду, у випадках, коли вартість позову не перевищує 5000 євро на момент отримання форми позову судом відповідної юрисдикції, не враховуючи всіх нарахувань, витрат і виплат. Це означає, що поняття дрібного позову включає справи з чітко встановленою вартістю позову.

Таким чином, співвідношення між поняттями двох спрощених процедур є досить складним. Однак можна стверджувати, що, незважаючи на те, що терміни "малозначна справа" та "дрібний позов" діють у спрощених процедурах, ці терміни не можуть бути взаємозамінними. На концептуальному рівні, дрібні позови можна певною мірою співвідносити лише з випадками, згаданими у ч. 6 ст. 19 ЦПК [3], тобто "справами, в яких ціна позову не перевищує ста розмірів прожиткового мінімуму для працездатних осіб", причому треба зазначити різницю у вартості позову в українських та європейських процедурах - 5000 та 6265 євро відповідно.

Переклад терміна "малозначна справа": оцінювання варіантів і вибір відповідника. Перекладаючи терміни, особливо, якщо ці терміни $є$ неологізмами, зазвичай застосовують такі методи перекладу: 1) пряме включення; 2) транскрипція або транслітерація; 3) описовий переклад; 4) калькування; 5) вибір варіантного еквівалента [2]. Щоб проілюструвати, як ці методи використовують у сфері юридичного перекладу, наведемо кілька прикладів з Угоди про асоціацію між Україною та ЄС. Так, зокрема, термін "acquis" не прийнято перекладати і він використовується в оригінальній формі в усіх 24 мовах ЄС, серед них і в українській мові. Інколи, за відсутності еквівалента в мові перекладу, можливе запозичення слів зі збереженням звукової або графічної форми слова мови оригіналу (наприклад, precursors прекурсори, prudential - пруденційний). Крім того, якщо існує потреба повністю розкрити понятійний зміст терміна, якого немає в мові перекладу, застосовують описовий переклад. Так, в Асоціації про Угоду зустрічаємо переклад "smuggling" як "незаконне переправлення через державний кордон нелегальних мігрантів". Калькування, буквальний або дослівний переклад полягає у виборі першого словникового варіанта для перекладу терміна. Так, наприклад, слово "international" можна перекласти транскрибуванням ("інтернаціональний"), а можна - калькуванням ("міжнародний"). Часто перший словниковий варіант перекладу терміна з певних причин не підходить, тому виникає необхідність вибрати варіантний відповідник перекладу багатозначного слова. Прикладом такого способу перекладу слугують: "national treatment", який перекладається українською як "національний режим", "anti-competitive" - "монополістичний".

Розглянемо детальніше, які з указаних вище методів доцільно застосовувати для перекладу терміна "малозначна справа" англійською мовою.

Українська й англійська мови належать до різних підгруп індоєвропейської мовної сім'ї, у яких використовують різні алфавіти - кирилицю й латиницю, тому за такого способу перекладу, як пряме включення та транскрипція, термін "maloznachnyi" виглядатиме досить штучно в англійському тексті. Існують лише поодинокі випадки, коли можлива транслітерація терміна для інформаційних цілей, передачі його звучання мовою оригіналу, часто у зносках до основного тексту.

Описовий переклад, як уже згадувалося раніше, $є$ дуже багатослівним методом перекладу. В юридичному дискурсі описовий переклад $є$ ще об'ємнішим, оскільки юридичні терміни мають дуже точне значення та вимагають детальних пояснень, й іноді, як у випадку з "ма- 
лозначною справою", лише пояснення цього терміна може займати окремий абзац. Це не означає, що описовий переклад терміна неможливий у юридичному дискурсі. В інформативних текстах термін може бути перекладений описово у виносці та використаний по всьому тексту в узгодженому скороченому вигляді або транскрибовано / транслітеровано.

Буквальним перекладом терміна "малозначна справа" $є$ "insignificant case". В англійській мові це може звучати досить неоднозначно через конотацію і загального, і юридичного характеру слова "insignificant". Так, Оксфордський словник англійської мови містить таке визначення "insignificant": 1. Занадто малий або неважливий, щоб бути вартим розгляду. 2. Безглуздий. Ще менш підходить вибір варіантного відповідника перекладу слова "малозначний": синонімічний ряд включає, зокрема "meaningless" (безглуздий), "irrelevant" (нерелевантний), "minor" (незначний). Усі вони, за винятком, можливо, останнього, мають неявно негативний підтекст. Слово "minor" могло б бути варіантом перекладу, але така можливість виключається, оскільки у другому його значенні - "неповнолітній" воно вже функціонує на позначення справ, пов'язаних із неповнолітніми.

3 проаналізованих варіантів можна дійти висновку, що переклад терміна "малозначна справа" вимагає прийняття компромісного рішення, оскільки кожен із перелічених способів має свої недоліки. У такій ситуації перекладач повинен вибрати найкращий варіант з існуючих, i, на наш погляд, найкращим варіантом $€$ буквальний переклад - "insignificant case" - оскільки він запроваджує в англійській мові новий термін, який не можна ототожнити з іншими юридичними термінами, та відповідає вимогам мовної економії. Щоб підтвердити цю точку зору, ми можемо звернутися до судової практики ЄСПЛ.

У справі "Катерина Макарівна Молдавська проти України" [14] ЄСПЛ, викладаючи обставини справи, використав переклад терміна "малозначна справа" англійською мовою як "insignificant case": "Article 12 of the Code, which defines types of commercial judicial proceedings, defines summary proceedings as "intended for the consideration of insignificant cases or cases of negligible complexity...". Як ми бачимо, ЄСПЛ використовує буквальний переклад "insignificant case". Вищевикладені положення можуть слугувати основою для подальших офріційних перекладів терміна "малозначна справа" як "insignificant case".

ВИСнОВКИ. Юридичний переклад - одна з найскладніших сфер перекладу, що вимагає глибокого розуміння правових традицій країн мови оригіналу та мови перекладу. Юридичний переклад з англійської мови на українську та навпаки став особливо актуальним у світлі угоди про асоціацію України та ЄС. у межах асоціації передбачається переклад великої кількості юридичних документів і розробкляння корпусу юридичної термінології ЄС-Україна. У процесі розробки термінологічної бази важливо дотримуватися рекомендацій щодо стандартизації та гармонізації концепцій і термінів. Також необхідно, щоб юридичні терміни національного законодавства не ототожнювали з наднаціональними термінами $€ C$, оскільки це може призвести до їх неправильного тлумачення.

Особливу увагу слід приділити перекладу юридичних неологізмів, які з'являються в результаті запровадження законодавчих новел. Серед останніх неологізмів в українському законодавстві запропоновано конце- пцію малозначної справи у сфері спрощеного цивільного процесу. Незважаючи на те, що цей термін подібний до терміна $€ C$ "small claim" (дрібний позов), проте він має ширше поняття. Щоб уникнути його помилкового ототожнення з терміном "small claims", рекомендується встановити перекладацький відповідник "малозначна справа" - "insignificant case". Цей погляд підтверджується практикою ЄСПЛ, де термін "малозначна справа" вже вживався у перекладі "insignificant case". 3 метою полегшення процесу перекладу законодавчих документів України та ЄС необхідно укладати та постійно доповнювати спеціальні термінологічні словники та забезпечити до них відкритий доступ.

Список використаних джерел

1. Візерінгтон Д. Складнощі перекладу. Обмін інформацією між англомовним світом та Україною [Електронний ресурс] / Д. Візерінгтон // Європейська правда (2015), 11 березня 2015. - Режим доступу: https://www.eurointegration.com.ua/experts/2015/03/11/7031726/.

2. Карабан В.І. Переклад англійської наукової і технічної літератури / В. І. Карабан. - Вінниця: Нова Книга, 2004. - 575 с.

3. Цивільний процесуальний кодекс України (зі змінами 2020 р.) Відомості Верховної ради України 40-41 (2004) [Електронний ресурс]. Режим доступу: https://zakon.rada.gov.ua/laws/show/1618-15\#Text.

4. Association Agreement between the European Union and its Member States, of the one part, and Ukraine, of the other part (2014) OJ L161/5.

5. Baklazhenko Yu.V. Ukrainian-English Translation of Legal Terms: A Case Study of Insignificant Cases and Small Claims. I Yu. Baklazhenko // Access to Justice in Eastern Europe. - 2021. - 1(9). - pp. 232-242. DOI: 10.33327/AJEE-18-4.1-n000055.

6. Biel L. Competencies for EU Legal Translation (Presentation given at the Conference 'EU Translated: Towards Better Quality Legal Translations for Better Implementation of the EU-Ukraine Association Agreement' [Електронний ресурс]. - Режим доступу: https://www.youtube.com/watch?v= gvfPGUio454\&list=PLbiaVfW3NyKCmyNQKkf96oQCz1L2Yud5U\&index=5 (in English)

7. Catford J.C. A Linguistic Theory of Translation / J.C. Catford. - Oxford: OUP, 1965. - $103 \mathrm{p}$.

8. Čavoški A. Interaction of law and language in the EU: Challenges of translating in multilingual environment [Електронний ресурc] / A. Čavoški // The Journal of Specialised Translation. - 2017. - No. 27. - p. 58. - Режим доступу: https://www.jostrans.org/issue27/art_cavoski.pdf

9. Defrancq, B. Principles of EU Legal English and Terminology (Presentation given at the Conference 'EU Translated: Towards Better Quality Legal Translations for Better Implementation of the EU-Ukraine Association Agreement' [Електронний ресурс]. - Режим доступу: https://www.youtube.com/watch?v=kxPpqzZBwzw\&t=141s.

10. Easterbrook $\mathrm{H}$. The Most Insignificant Justice: Further Evidence [Електронний ресурс] / H. Easterbook // The University of Chicago Law Review. - 1983. - No. 50. - p. 481. - Режим доступу: https://core.ac.uk/ download/pdf/234129303.pdf (in English).

11. Terminology work - Harmonization of concepts and terms: ISO 860:2007(en) [Електронний ресурc]. - Режим доступу: https://www.iso.org/ obp/ui/\#iso:std:iso:860:ed-3:v1:en.

12. Izarova I. O., Prytyka, Y. D. Simplified lawsuit of civil proceedings in Ukraine: the challenges of the first year of application in judicial practice / I.O. Izarova, Y.D. Prytyka // Problems of Legality. - 2019. - No. 145. pp. 51-67. https://doi.org/10.21564/2414-990x.145.160567.

13. Jarabik B. Status of the A4U Project and the AA/DCFTA Implementation in December 201 / B. Jarabik // Reviews-Comments-Briefs A4U. 2018. - (18) [Електронний ресурс]. - Режим доступу: https://eu-ua.org/ sites/default/files/inline/files/a4u_reviews-comments-briefs_n18_status_of_ the a4u project and the aa-dcfta impl. in dec. 2018 .pdf.

14. Kateryna Makarivna Moldavska $v$ Ukraine (App No 43464/18) ECtHR, 14 May 2019 [Електронний ресурc]. - Режим доступу: http://hudoc.echr.coe.int/eng?i=001-193900 (in English).

15. Koller W. Grundprobleme der Übersetzungstheorie. Unter besonderer Berücksichtigung schwedisch-deutscher Übersetzungsfäll / W. Koller // Stockholmer germanistische Forschungen. - 1972. - No. 9. - p. 181.

16. Ladmiral J.R. La traduction comme linguistique d'invention / JR Ladmiral // W. Pockl (ed), Europaische Mehrsprachigkeit. Festschrift zum 70. Geburtstag von Mario Wandruszka. - Tubingen Niemeyer, 1981.

17. Mac Aodha M. Legal translation -an impossible task? / M. Mac Aodha // Semiotica. - 2014. - 201 (1-4) - - p.207.

18. Pym A. Exploring Translation Theories / A. Pym. - Routledge, 2010.

19. Regulation (EU) $2015 / 2421$ of the European Parliament and of the Council of 16 December 2015 amending Regulation (EC) No 861/2007 establishing a European Small Claims Procedure and Regulation (EC) No $1896 / 2006$ creating a European order for payment procedure [Електронний ресурс]. - Режим доступу: https://eur-lex.europa.eu/legal-content/EN/TXT/ PDF/?uri=CELEX:32015R2421\&from=EN (in English) 
20. Reiss K., Vermeer H.J. Towards a General Theory of Translational Action: Skopos Theory Explained / Reiss K., Vermeer H.J. - Routledge, 2014.

21. Stern L. Book review of Translation Issues in Language and Law by F. Olsen, A. Lorz D. Stein (eds) / L. Stern // The International Journal of Speech, Language and the Law. - 2009. - 17 (1). - p. 161.

22. Wolff L. Legal Translation / L. Wolf // The Oxford Handbook of Translation. - Oxford: OUP, 2011. - 228-242.

\section{References}

1. Association Agreement between the European Union and its Member States, of the one part, and Ukraine, of the other part (2014) OJ L161/5 (in English).

2. Baklazhenko, Yu. (2021). Ukrainian-English Translation of Legal Terms: A Case Study of Insignificant Cases and Small Claims. Access to Justice in Eastern Europe, 1(9), 232-242. DOI: 10.33327/AJEE-18-4.1n000055.

3. Biel, L. (2019). Competencies for EU Legal Translation (Presentation given at the Conference 'EU Translated: Towards Better Quality Legal Translations for Better Implementation of the EU-Ukraine Association Agreement'. https://www.youtube.com/watch?v=gvfPGUio454\&list=PLbia VfW3NyKCmyNQKkf96oQCz1L2Yud5U\&index=5 (in English).

4. Catford, J.C. (1965). A Linguistic Theory of Translation. Oxford: OUP (in English).

5. Čavoški, A. (2017). Interaction of law and language in the EU: Challenges of translating in multilingual environment. The Journal of Specialised Translation, (27), 58. https://www.jostrans.org/issue27/art_cavoski.pdf (in English).

6. Defrancq, B. (2019). Principles of EU Legal English and Terminology (Presentation given at the Conference 'EU Translated: Towards Better Quality Legal Translations for Better Implementation of the EU-Ukraine Association Agreement'. https://www.youtube.com/watch?v=kxPpqzZBwzw\&t= 141s (in English)

7. Easterbrook, H. (1983). The Most Insignificant Justice: Further Evidence, The University of Chicago Law Review, (50), 481. https://core.ac.uk/ download/pdf/234129303.pdf (in English).

8. ISO 860:2007(en). (2007). Terminology work - Harmonization of concepts and terms. https://www.iso.org/obp/ui/\#iso:std:iso:860:ed-3:v1:en (in English).

9. Izarova, I. O., \& Prytyka, Y. D. (2019). Simplified lawsuit of civil proceedings in Ukraine: the challenges of the first year of application in judicial practice. Problems of Legality, (145), 51-67. https://doi.org/10.21564/2414990x.145.160567.

10. Jarabik, B. (2018). Status of the A4U Project and the AA/DCFTA Implementation in December 2018. Reviews-Comments-Briefs A4U, (18). https://eu-ua.org/sites/default/files/inline/files/a4u_reviews-comments-briefs_ n18_status_of_the_a4u_project_and_the_aa-dcfta_impl._in_dec._2018_pdf. (in English)

11. Karaban, V.I. (2004). Pereklad anhliiskoi naukovoi I tehnichnoi literatury [Translation of English Scientific and Technical Literature]. 4th edn, Vinnytsia: Nova Knyha (in Ukrainian).

12. Kateryna Makarivna Moldavska v Ukraine (App No 43464/18) ECtHR, 14 May 2019 http://hudoc.echr.coe.int/eng?i=001-193900 (in English).

13. Koller, W. (1972). Grundprobleme der Übersetzungstheorie. Unter besonderer Berücksichtigung schwedisch-deutscher Übersetzungsfälle. Stockholmer germanistische Forschungen, (9), 181.

14. Ladmiral, J.R. (1981). La traduction comme linguistique d'invention in W. Pockl (ed), Europaische Mehrsprachigkeit. Festschrift zum 70. Geburtstag von Mario Wandruszka. Tubingen Niemeyer (in German).

15. Mac Aodha, M. (2014). Legal translation -an impossible task? Semiotica, 201 (1-4), 207.

16. Pym, A. (2010). Exploring Translation Theories, Routledge (in English)

17. Regulation (EU) $2015 / 2421$ of the European Parliament and of the Council of 16 December 2015 amending Regulation (EC) No 861/2007 establishing a European Small Claims Procedure and Regulation (EC) No $1896 / 2006$ creating a European order for payment procedure. https://eur-lex.europa.eu/legal-content/EN/TXT/PDF/?uri=CELEX:32015R2421 \&from=EN (in English).

18. Reiss, K. \& Vermeer, H.J. (2014). Towards a General Theory of Translational Action: Skopos Theory Explained. Routledge (in English)

19. Stern, L. (2009). Book review of Translation Issues in Language and Law by F. Olsen, A. Lorz D. Stein (eds). The International Journal of Speech, Language and the Law, 17 (1), 161(in English).

20. Tsyvilnyi procesualnyi kodeks Ukrainy [Civil Procedure Code of Ukraine] (with amendments of 2020) Vidomosti of the Verkhovna Rada Ukrainy 40-41 (2004). https://zakon.rada.gov.ua/laws/show/1618-15\#Text (in Ukrainian).

21. Vizerington, J. (2015). Skladnoshchi perekladu. Obmin informatsiyeyu mizh anhlomovnym svitom ta Ukrayinoyu [Translation Difficulties. Information Exchange between English-speaking World and Ukraine]. Europeiska Pravda, 11 March 2015. https://www.eurointegration.com.ua/ experts/2015/03/11/7031726/ (in Ukrainian).

22. Wolff, L. (2011). Legal Translation, The Oxford Handbook of Translation Studies.

Received: $14 / 04 / 2021$

Accepted: $28 / 05 / 2021$

Yu. Baklazhenko, PhD, Associate Prof

National University of Ukraine 'Igor Sikorskyi Kyiv Polytechnic Institute', Kyiv, Ukraine

\section{TRANSLATION OF LEGAL NEOLOGISMS ON THE EXAMPLE OF THE TERM "INSIGNIFICANT CASE"}

The article deals with the issue on translating legal terms from Ukrainian into English on the basis of a case study of a newly-coined term in Ukrainian legislation - 'maloznachna sprava'. The relevance of the topic of legal translation from English into Ukrainian and vice versa has become especially acute in light of the Ukraine-EU approximation agreement. While the introduction of simplified civil proceedings is itself a step towards the approximation of Ukrainian legislation to the EU, the next stage will inevitably be comparing and contrasting the existing terms within the Ukrainian and EU civil procedures. Ukrainian simplified procedure aims at considering insignificant cases (Ukr. - 'maloznachni spravy') in a speedy manner, while EU accelerated and simplified civil procedure uses the term 'small claims' for cases with a claim value for up to EUR 5,000. Obviously, these notions are not equivalent, but their meaning overlaps, creating pitfalls for translation. Thus, for proper translation, it is important to specify how the concept of small claims fits into Ukraine's national context. The notion of insignificant cases illustrates the relevance of the linguistic study of legal translations, as well as a need for the consolidation of practical achievements in the field of translation of legal discourse and, in particular, legal neologisms. The purpose of legal translation is to create a text that will be interpreted in the same way by legal professionals in the target legal system as it would be in the original legal system. The aim of translation is not to erase linguistic and cultural differences but to accommodate them, fully and unapologetically. The challenge is to convey the legal text as a fragment of a living legal system. When translating, a translator should strive for equivalence, bearing in mind the harmonisation and approximation of terminologies. The linguistic approximation of national Ukrainian legal terms to the EU terminology should be carefully considered to avoid their misinterpretation with the supranatural terms. The author emphasises the necessity to perform concept analysis between the terms in the EU and Ukraine simplified procedures and comes to the conclusion that despite having surface similarity to the EU term 'small claim', the Ukrainian term 'maloznachna sprava' is, in fact, a much wider concept. A range of translations of legal neologisms are described in the article, and the need to use a literal translation of the term is substantiated. As a result of the analysis of possible translation options and the ECtHR translation precedent, it is recommended that the term 'maloznachna sprava' should be translated as 'insignificant case' within the sphere of Ukrainian civil procedure.

Keywords: legal translation, Ukrainian-English translation, small claim, insignificant case. 